\title{
REVIEWS
}

\section{Vitamin D: A Narrative Review Examining the Evidence for Ten Beliefs}

\author{
G. Michael Allan, $M D^{7}$, Lynda Cranston, BA ${ }^{2}$, Adrienne Lindblad, PharmD', \\ James McCormack, PharmD ${ }^{3}$, Michael R. Kolber, MD, MSc ${ }^{7}$, Scott Garrison, MD, PhD ${ }^{7}$, and \\ Christina Korownyk, $M D^{7}$
}

${ }^{1}$ Evidence-Based Medicine, Department of Family Medicine - Research Program, University of Alberta, Edmonton, AB, Canada; ${ }^{2}$ The Foundation for Medical Practice Education, Hamilton, ON, Canada; ${ }^{3}$ Faculty of Pharmaceutical Sciences, University of British Columbia, Vancouver, BC, Canada.

Over the past decade, a large body of observational evidence has suggested an association between lower vitamin D status (25-hydroxyvitamin D) and multiple acute and chronic disorders, including cancer, multiple sclerosis, depression and respiratory tract infections. This evidence has fostered the hypothesis that increasing vitamin D intake may treat and prevent such disorders. Our objective was to perform a critical analysis of the highestlevel evidence for ten common beliefs regarding vitamin $\mathrm{D}$ for the prevention of falls, fractures and respiratory tract infections, the reduction of cancer incidence/mortality and overall mortality, and the prevention or treatment of depression/mental well-being, rheumatoid arthritis and multiple sclerosis, as well as maximum dosing and regular testing. We searched the Cochrane Database of Systematic Reviews and PubMed (up to August 2014) for randomized controlled trials and systematic reviews/ meta-analyses based on those studies. All searches were performed, all evidence reviewed and each section written by at least two authors. The evidence shows that vitamin D supplementation provides some benefit in fracture prevention (likely $\sim 10-15 \%$ relative reduction), particularly at a dose $\geq 800$ IU and with calcium; a likely benefit in the rate of falls, though it is less clear whether the number of fallers changes; and a possible small ( $\sim 5 \%)$ relative reduction in mortality. Evidence does not support the use of vitamin D supplementation for the prevention of cancer, respiratory infections or rheumatoid arthritis. Similarly, evidence does not support vitamin D supplementation for the treatment of multiple sclerosis and rheumatoid arthritis or for improving depression/mental well-being. Regular testing of 25-hydroxyvitamin $\mathrm{D}$ is generally not required, and mega-doses ( $\geq 300,000$ IU) appear to increase harms. Much of the evidence is at high risk of bias, with multiple flaws, including analyses of secondary endpoints, small and underpowered studies, inconsistent results and numerous other issues. Therefore, enthusiasm for a vitamin D panacea should be tempered.

Electronic supplementary material The online version of this article (doi:10.1007/s11606-016-3645-y) contains supplementary material, which is available to authorized users.

Received July 13, 2015

Revised November 9, 2015

Accepted February 16, 2016

Published online March 7, 2016
KEY WORDS: vitamin D; mortality; fracture; falls; depression; upper respiratory tract infection.

$\mathrm{J}$ Gen Intern Med 31(7):780-91

DOI: $10.1007 / \mathrm{s} 11606-016-3645-y$

(C) Society of General Internal Medicine 2016

\section{VITAMIN D: EXAMINING THE EVIDENCE FOR TEN BELIEFS}

Over the past decade, more than 1600 studies have been conducted on vitamin $\mathrm{D}$, and more than half of these are cohort or observational studies demonstrating an association between deficits in vitamin $\mathrm{D}$ and a litany of acute and chronic disorders - cardiovascular disease, cancer, diabetes, fractures, depression and respiratory tract infections, to name a few. ${ }^{1}$ These findings have fueled the hypothesis that vitamin D supplementation - a widely available, low-cost and mostly harmless intervention - might treat or even prevent these disorders.

Association, however, is not causation. Observational studies are not sufficient for proving that low concentrations of vitamin D (measured as 25-hydroxyvitamin D [25-OHD] level) cause disease, or that increasing levels would improve health. ${ }^{1}$ Only high-quality randomized controlled trials (RCTs), and resulting high-quality systematic reviews and meta-analyses, can determine whether vitamin D supplementation influences clinical outcomes.

This article will explore ten common beliefs regarding vitamin $\mathrm{D}$ based on the available evidence. Although not always consistent, the first eight beliefs originate from observational studies or theories drawing an association between low 25-OHD level and increased risk or severity of the following medical concerns: falls, ${ }^{2-4}$ fractures, ${ }^{5,6}$ respiratory tract infections, ${ }^{7}$ depression/mental well-being, ${ }^{8}$ rheumatoid arthritis, ${ }^{9,10}$ multiple sclerosis, ${ }^{5,11-13}$ overall mortality ${ }^{14,15}$ and cancer. ${ }^{16}$ The last two beliefs involve the practical dilemmas of dosing and routine testing.

\section{BELIEF 1: VITAMIN D REDUCES FALLS}

\section{Observational Studies}

Small observational studies (3 studies, $n=1981$ ) have found an association between low vitamin D levels and falls among 
elderly patients in long-term care. ${ }^{2-4}$ As a result, investigators have postulated that vitamin D supplementation may reduce the risk of falling.

\section{Systematic Review/Meta-Analysis}

Eight meta-analyses ${ }^{17-24}$ of vitamin D levels and falls have been conducted, some with conflicting results. Online Table A provides an overview of these meta-analyses, including populations, outcomes and other methodological issues.

When considering this evidence, the analysis of "falls" rather than "fallers" in many RCTs is a key issue. An analysis of "falls" means that people who fell more than once were counted more than once in the primary outcome analysis. These studies generally lacked the statistical power to detect a significant difference in the number of "fallers" (people that fell one or more times). They relied, therefore, on repeat falls to obtain the desired number of total falls.

The most current systematic review included a trial sequential analysis ${ }^{24}$ (a method to identify the ideal sample size of a meta-analysis and to potentially reduce false-positive results). It showed that the effect estimate for vitamin $\mathrm{D}$, with or without calcium, lay within the futility boundary, i.e., that it did not alter the relative risk (RR) of falls by $15 \%$ or more. Using a risk reduction threshold of $10 \%$, a sensitivity analysis (a method to assess the impact of key variables on a study's conclusions) found that the effect estimate also lay within the futility boundary.

\section{Bottom Line}

Vitamin D supplementation may reduce the number of falls among the elderly. There is also likely an overall reduction in the number of "fallers" (a less biased outcome), although these results are less consistent.

\section{BELIEF 2: VITAMIN D REDUCES FRACTURES}

\section{Observational Studies}

For the most part, more recent observational studies are consistent with older studies that have established a relationship between low vitamin D levels and fractures. ${ }^{5}$ A systematic review and meta-analysis of observational studies (17 case-control studies, $n=1903$ hip fracture cases and 1953 controls) found $33 \%$ lower vitamin D levels in cases compared to controls. This difference was significantly greater in studies with population-based versus hospital-based controls. ${ }^{6}$

\section{Systematic Reviews/Meta-Analyses}

There are many systematic reviews of vitamin D supplementation and fracture prevention. We focus on five large reviews published within the last 5 years with meta-analyses on fracture prevention (Table 1).
Vitamin D alone did not appear to reduce hip, non-vertebral or total fractures. ${ }^{25,27,28}$ When vitamin D was combined with calcium, the RR reductions were significant for total or nonvertebral fracture ${ }^{25-29}$ and hip fractures, ${ }^{25,28}$ with two results non-significant for hip fractures. ${ }^{26,29}$

Two of the systematic reviews ${ }^{26,29}$ found that higher doses of vitamin D ( $>400 \mathrm{IU}$ or a median dose of $800 \mathrm{IU})$ resulted in better and statistically significant RR reductions for nonvertebral and hip fractures. Although co-administration of calcium is important, it appears that doses $<1000 \mathrm{mg}$ are just as effective as higher doses. ${ }^{26}$

The most recent of these included a trial sequential analysis $^{25}$ showing that the effect estimate for vitamin $\mathrm{D}$, with or without calcium, was less than the futility boundary of $15 \%$ RR reduction of total fractures. Furthermore, this effect is unlikely to be meaningfully changed by future studies. However, uncertainty remains around hip fracture, with more research needed to determine whether vitamin $\mathrm{D}$ with calcium results in a meaningful reduction in hip fractures $(\geq 15 \%)$.

\section{Bottom Line}

The best available evidence shows an apparent reduction in fractures associated with vitamin $\mathrm{D}$ when given at moderate doses ( $\geq 800 \mathrm{IU} /$ day) together with calcium at low to moderate doses (perhaps $500 \mathrm{mg} /$ day). The RR reductions are approximately $10-15 \%$ for non-vertebral/total or hip fractures. At a $15 \%$ baseline risk of any fracture, approximately 45-67 individuals would have to take vitamin D and calcium every day for 10 years to prevent one fracture.

\section{BELIEF 3: VITAMIN D REDUCES RESPIRATORY TRACT INFECTIONS}

\section{Observational Studies}

A large cohort study $(n=18,883$, age $\geq 12)$ suggested that upper respiratory tract infections (RTIs) are more common in people with low vitamin D levels and less common in those with high vitamin D levels. ${ }^{7}$

\section{Systematic Reviews/Meta-Analyses}

Three recent systematic reviews/meta-analyses ${ }^{30-32}$ (Table 2) have explored vitamin D supplementation and RTIs.

The Bergman $2013^{30}$ and Charan $2012^{31}$ reviews concluded that vitamin D provided a protective effect against RTIs. The third, Mao 2013, ${ }^{32}$ found no effect. All three studies have weaknesses in design and implementation, but the first two ${ }^{30,31}$ have the greatest concerns. For example, they included RCTs from heterogeneous populations: children under the age of 3 with pneumonia from an impoverished area of Afghanistan and healthy adult volunteers from Long Island, New York. The Mao 2013 review limited some of the clinical variability by focusing on healthy subjects. ${ }^{32}$ 
Table 1 Vitamin D (With or Without Calcium) and Fracture (Systematic Reviews)

\begin{tabular}{|c|c|c|c|c|c|}
\hline $\begin{array}{l}\text { Systematic review/ } \\
\text { Meta-analysis }\end{array}$ & Bolland 2014 25 & $\begin{array}{l}\text { Bischoff-Ferrari } \\
2012^{26}\end{array}$ & Chung 2011 & Avenell 2014 & $\begin{array}{l}\text { Bischoff-Ferrari } \\
2009^{29}\end{array}$ \\
\hline Population & $\begin{array}{l}\text { Mean age } 56-89 \text {, } \\
24-100 \% \text { women }\end{array}$ & $\begin{array}{l}\text { Mean age } 76, \\
91 \% \text { women }\end{array}$ & $\begin{array}{l}69 \% \\
\text { post-menopausal } \\
\text { women age }>65\end{array}$ & $\begin{array}{l}\text { Mean age } 71.3 \text {, } \\
89 \% \text { women }\end{array}$ & $89 \%$ women \\
\hline $\begin{array}{l}\text { Non-vertebral } \\
\text { fracture* }\end{array}$ & Not provided & $\begin{array}{l}\text { RR } 0.93(95 \% \\
\text { CI } 0.87-0.99)\end{array}$ & Not provided & $\begin{array}{l}\text { We present total } \\
\text { fracture (below) }\end{array}$ & $\begin{array}{l}\text { RR } 0.86(95 \% \\
\text { CI } 0.77-0.96)\end{array}$ \\
\hline Total Fracture* & $\begin{array}{l}\mathrm{RR} 0.95 \\
(95 \% \mathrm{CI} \\
0.88-1.02)\end{array}$ & Not provided & $\begin{array}{l}\text { RR } 0.88(95 \% \\
\text { CI } 0.78-0.99)\end{array}$ & $\begin{array}{l}\text { RR } 0.95(95 \% \\
\text { CI } 0.90-0.99)\end{array}$ & Not provided \\
\hline $\begin{array}{l}\text { Number of } \\
\text { randomized } \\
\text { controlled trials } \\
\text { (patients) }\end{array}$ & $25(76,497)$ & $11(31,022)$ & $11(52,915)$ & $10(49,976)$ & $12(42,279)$ \\
\hline Heterogeneity & $I^{2}=33 \%$ & Not provided & $I^{2}=36 \%$ & $I^{2}=8 \%$ & $Q$ test, $p=0.04$ \\
\hline $\begin{array}{l}\text { Sensitivity } \\
\text { analysis }\end{array}$ & $\begin{array}{l}\text { Vitamin D alone } \\
\text { not statistically } \\
\text { significant, but } \\
\text { vitamin D with } \\
\text { calcium was: } \\
\text { RR } 0.92(95 \% \\
\text { CI } 0.85-0.99)\end{array}$ & $\begin{array}{l}\text { Only the } 800-\mathrm{IU} / \text { day } \\
\text { dose showed a } \\
\text { difference: } \\
\text { RR } 0.86(95 \% \\
\text { CI } 0.76-0.96)\end{array}$ & $\begin{array}{l}\text { No effect of } \\
\text { vitamin D } \\
\text { alone }\end{array}$ & $\begin{array}{l}\text { Vitamin D alone } \\
\text { no difference in } \\
\text { any fracture }\end{array}$ & $\begin{array}{l}\text { Dose } \leq 400 \mathrm{IU} / \text { day: } \\
\text { RR } 1.02(95 \% \\
\text { CI } 0.92-1.15) \\
\text { Dose }>400 \mathrm{IU} / \text { day: } \\
\text { RR } 0.80(95 \% \\
\text { CI } 0.72-0.89)\end{array}$ \\
\hline Hip fracture* & $\begin{array}{l}\text { RR } 0.97(95 \% \\
\text { CI } 0.86-1.08)\end{array}$ & $\begin{array}{l}\text { RR } 0.90(95 \% \\
\text { CI } 0.80-1.01)\end{array}$ & Not provided & $\begin{array}{l}\text { RR } 0.84(95 \% \\
\text { CI } 0.74-0.96)\end{array}$ & $\begin{array}{l}\text { RR } 0.91(95 \% \\
\text { CI } 0.78-1.05)\end{array}$ \\
\hline $\begin{array}{l}\text { Number of } \\
\text { randomized controlled } \\
\text { trials (patients) }\end{array}$ & $21(75,179)$ & $11(31,022)$ & Not provided & $9(49,853)$ & $8(40,886)$ \\
\hline Heterogeneity & $I^{2}=14 \%$ & Not provided & Not provided & $I^{2}=0 \%$ & $Q$ test, $p=0.08$ \\
\hline Sensitivity analysis & $\begin{array}{l}\text { Vitamin D alone } \\
\text { not statistically } \\
\text { significant, but } \\
\text { vitamin D with } \\
\text { calcium was: } \\
\text { RR } 0.84 \\
(95 \% \text { CI } \\
0.74-0.96)\end{array}$ & $\begin{array}{l}\text { Only the } 800 \\
\text { IU/day dose showed } \\
\text { a difference: } \\
\text { RR } 0.70(95 \% \\
\text { CI } 0.58-0.86)\end{array}$ & Not provided & $\begin{array}{l}\text { Vitamin D alone } \\
\text { had no effect }\end{array}$ & $\begin{array}{l}\text { Dose } \leq 400 \mathrm{IU} / \text { day: } \\
\text { RR } 1.09(95 \% \\
\text { CI } 0.90-1.32) \\
\text { Dose }>400 \mathrm{IU} / \text { day: } \\
\text { RR } 0.82(95 \% \\
\text { CI } 0.69-0.97)\end{array}$ \\
\hline Other issues & $\begin{array}{l}\text { Strengths: } \\
\text { Included trial } \\
\text { sequential and } \\
\text { futility analysis } \\
\text { (see text) }\end{array}$ & $\begin{array}{l}\text { Weaknesses: Used } \\
\text { patient-level data } \\
\text { Two studies without } \\
\text { patient-level data } \\
\text { ("source data") } \\
\text { excluded from } \\
\text { primary analysis }\end{array}$ & $\begin{array}{l}2 \text { studies: } \\
\text { good quality } \\
5 \text { studies: } \\
\text { fair quality } \\
4 \text { studies: } \\
\text { poor quality } \dagger\end{array}$ & $\begin{array}{l}\text { Weaknesses: } \\
\text { Population not } \\
\text { summarized } \\
\text { (we did with RCTs) } \\
24 \text { of } 52(46 \%) \\
\text { studies lack } \\
\text { information on } \\
\text { randomization }\end{array}$ & $\begin{array}{l}\text { Estimated } \\
\text { non-vertebral } \\
\text { (high-dose) number } \\
\text { needed to treat of } 93 \\
\text { over } 12-84 \text { months } \\
\text { Hip (high-dose) } \\
\text { number needed to } \\
\text { treat of } 168 \text { over } \\
12-84 \text { months }\end{array}$ \\
\hline
\end{tabular}

$R R$ relative risk

* Pooled results of vitamin D with or without calcium, except Avenell 2014, which is vitamin D with calcium only

† According to AHRQ Methods Reference Guide for Effectiveness and Comparative Effectiveness Reviews

Bergman $2013^{30}$ and Charan $2012^{31}$ used odds ratios, which can exaggerate the relative effectiveness of interventions in common events such as upper RTIs. For example, the risk reduction from the Laaksi $\mathrm{RCT}^{33}$ (a trial included in each of the three meta-analyses) was reported as $33 \%$ in Bergman $2013^{30}$ and $43 \%$ in Charan $2012,{ }^{31}$ but only $12 \%$ in Mao 2013. ${ }^{32}$ Bergman $2013^{30}$ and Charan $2012^{31}$ also included the influenza A-only results (with a $47 \%$ reduction) from one study ${ }^{34}$ rather than all flu outcomes (with a $3 \%$ reduction) as reported by Mao 2013. ${ }^{32}$ All in all, the Bergman $2013^{30}$ and Charan $2012^{31}$ results are unreliable, particularly for healthy western populations. The Mao $2013^{32}$ meta-analysis was not without concern-for example, $75 \%$ of the weighting was given to one of the seven trials. Overall, however, Mao $2013^{32}$ was likely the most reliable analysis, and found that vitamin D had no effect in reducing RTIs.
In this case, it is probably more helpful to examine the individual RCTs. A Tools for Practice article (evidence synopsis) ${ }^{35}$ summarized 11 RCTs. The RCT of highest quality and greatest application to western populations, Murdoch 2012, ${ }^{36}$ found that vitamin D supplementation over two winters did not reduce cold or flu illness in 322 New Zealand university and/or health care workers. The majority of other trials, including a large trial of infants in Kabul Afghanistan, ${ }^{37}$ did not find a reduction in respiratory infections. One trial of Mongolian children with profound vitamin D deficiency $(17.5 \mathrm{nmol} / \mathrm{L})$ found a reduction of 0.35 respiratory tract infections over 3 months. ${ }^{38}$

\section{Bottom Line}

Vitamin D supplementation does not prevent or reduce RTIs in western populations. There may be some benefit in children 
Table 2 Vitamin D and Respiratory Tract Infections (Systematic Reviews)

\begin{tabular}{|c|c|c|c|}
\hline $\begin{array}{l}\text { Systematic review/ } \\
\text { Meta-analysis }\end{array}$ & Bergman $2013^{30}$ & Mao $2013^{32}$ & Charan $2012^{31}$ \\
\hline Population & $\begin{array}{l}50 \% \text { men, } 50 \% \\
\text { women, average } \\
\text { age } 16 \text { years }\end{array}$ & $\begin{array}{l}\text { Men and women, } \\
\text { age range: } 1.75-63 \text { years }\end{array}$ & $\begin{array}{l}\text { Adult and pediatric, } \\
\text { male and female }\end{array}$ \\
\hline $\begin{array}{l}\text { Number of } \\
\text { randomized } \\
\text { controlled } \\
\text { trials (patients) }\end{array}$ & $11(5660)$ & $7(4827)$ & $5(1868)$ \\
\hline Vitamin D & $\begin{array}{l}1600 \mathrm{IU} / \text { day } \\
\text { Dose interval: } 24 \mathrm{~h} \\
\text { to } 3 \text { months }\end{array}$ & $\begin{array}{l}\text { Range: } \\
\text { 400-6800 IU/day } \\
2 \text { studies: } \\
\text { 100,000 IU quarterly } \\
200,000 \text { IU quarterly }\end{array}$ & Range: 400-2000 IU/day \\
\hline Duration & 7 weeks to 18 months & $1.75-18$ months & 6 months to 3 years \\
\hline Outcome & $\begin{array}{l}\text { Respiratory tract } \\
\text { infections in vitamin D } \\
\text { and placebo groups }\end{array}$ & $\begin{array}{l}\text { Respiratory tract infections } \\
\text { in vitamin } \mathrm{D} \text { and } \\
\text { placebo groups }\end{array}$ & $\begin{array}{l}\text { Respiratory tract infections } \\
\text { in vitamin D and placebo } \\
\text { groups }\end{array}$ \\
\hline Result & $\begin{array}{l}\text { Pooled odds ratio } 0.67 \\
(95 \% \text { CI } 0.50-0.88)\end{array}$ & $\begin{array}{l}\text { Pooled RR } 0.98 \\
(95 \% \text { CI } 0.93-1.03)\end{array}$ & $\begin{array}{l}\text { Pooled odds ratio } 0.582 \\
(95 \% \text { CI } 0.417-0.812)\end{array}$ \\
\hline Heterogeneity & $\begin{array}{l}\text { Significant } \\
\mathrm{Q}=35.7 ; I^{2}=72 \%\end{array}$ & Non-significant & $\begin{array}{l}\text { Significant } \\
t^{2}=0.064\end{array}$ \\
\hline Study quality & $\begin{array}{l}2 \text { studies: high } \\
\text { risk of bias } \\
9 \text { studies: low risk } \\
\text { of bias }\end{array}$ & All high quality & $\begin{array}{l}2 \text { studies: high quality* } \\
2 \text { studies: moderate* } \\
1 \text { study: poor quality* }\end{array}$ \\
\hline Other issues & $\begin{array}{l}\text { Weaknesses: Trials conc } \\
\text { among diverse age grou }\end{array}$ & $\begin{array}{l}\text { Weaknesses: No } \\
\text { evidence of publication } \\
\text { bias noted } \\
\text { Vitamin D dosing } \\
\text { regimens varied widely } \\
\text { veneous populations (Afghan } \\
\text { vitamin D levels at baseline }\end{array}$ & $\begin{array}{l}\text { Weaknesses: Publication } \\
\text { bias not checked } \\
\text { Two studies had } \\
\text { incomplete outcome data } \\
\text { pe, New Zealand) and }\end{array}$ \\
\hline
\end{tabular}

$R R$ relative risk

*According to GRADE Working Group

with profound vitamin D deficiency in developing countries, but this cannot be applied to all those countries.

\section{BELIEF 4: VITAMIN D IMPROVES DEPRESSION AND MENTAL WELL-BEING}

\section{Observational Studies}

A systematic review and meta-analysis $(n=31,424)$ assessed observational data on the relationship between vitamin $\mathrm{D}$ and depression. The systematic review included one case-control study which found that patients with depression had lower vitamin D levels than did healthy controls. The mean difference between the groups was $17.5 \mathrm{nmol} / \mathrm{L}$. Three cohort studies also included in the review explored the association between vitamin $\mathrm{D}$ levels and the risk of developing depression. Results showed a significantly increased risk of depression in patients with low vitamin D levels (hazard ratio $2.21,95 \%$ CI $1.40-3.40){ }^{8}$

\section{RCTs}

Many of the RCTs on mental health and vitamin D are at high risk of bias, with poor randomization, lack of blinding, no description of patient characteristics, no intention-to-treat analysis and large loss to follow-up.
Online Table B includes 8 RCTs that used vitamin D supplementation to improve mental well-being or depression. ${ }^{39-46}$ Depression was not a requirement for inclusion in these studies. Based on low baseline depression scores, limited improvements in depression scales would be possible. None of the RCTs that included primarily patients without depression demonstrated a meaningful change in depression or mental well-being.

Table 3 includes three RCTs of patients with depression or depressive symptoms. Mozaffair-Khosravi $2013^{47}$ showed a statistically and clinically significant improvement in symptoms, but had several methodological flaws, including unclear randomization and allocation concealment, and no blinding or intention-to-treat analysis. Khoraminya $2012^{49}$ also demonstrated a statistically and clinically significant improvement in symptoms. This trial was small and of short duration, and had methodological weaknesses. Yalamanchili $2012^{48}$ found that vitamin D had no statistically significant effect on depression. Although this was a secondary analysis, there was no indication of a positive effect.

\section{Systematic Reviews/Meta-Analyses}

Three systematic reviews of RCTs on vitamin D supplementation and depression scores have recently been completed. ${ }^{50-52}$ The conflicting results are shown in Table 4. 
Table 3 Vitamin D and Depression (Randomized Controlled Trials)

\begin{tabular}{|c|c|c|c|}
\hline $\begin{array}{l}\text { Randomized } \\
\text { controlled trial }\end{array}$ & Mozaffari-Khosravi 2013 $^{47}$ & Yalamanchili $2012^{48}$ & Khoranimya $\mathbf{2 0 1 2}^{49}$ \\
\hline Population & Mean age $\sim 32$, vitamin $\mathrm{D}<40 \mathrm{nmol} / \mathrm{L}$, Iran & $\begin{array}{l}\text { Community women, mean age } 71 \text {, } \\
\text { secondary analysis osteoporosis study }\end{array}$ & $\begin{array}{l}\text { Major depressive disorder, mean } \\
\text { age 39, Iran }\end{array}$ \\
\hline $\begin{array}{l}\text { Number of } \\
\text { participants }\end{array}$ & 120 & 489 (subgroup of 57 depressed) & \\
\hline Vitamin D & $\begin{array}{l}\text { Intramuscular injections: } 1 \text { dose of } 300,000 \\
\text { or } 150,000 \text { IU or nothing }\end{array}$ & $0.25 \mathrm{~g}$ calcitriol twice/day vs. placebo & $\begin{array}{l}1500 \mathrm{IU} \text { oral daily }+20 \mathrm{mg} \\
\text { fluoxetine vs. fluoxetine alone }\end{array}$ \\
\hline Duration & 1 year & 3 years & 8 weeks \\
\hline $\begin{array}{l}\text { Outcome and } \\
\text { baseline }\end{array}$ & $\begin{array}{l}\text { Beck Depression Inventory-II, score: } 27 \\
(\text { all }>17)\end{array}$ & $\begin{array}{l}\text { Geriatric Depression Scale, overall: } 4.8 \text {; } \\
12 \% \text { had depression (Geriatric Depression } \\
\text { Scale }>10 \text { ) }\end{array}$ & $\begin{array}{l}\text { Beck Depression Inventory, } \\
\text { score: } 32 \\
\text { Hamilton Depression Rating } \\
\text { Scale, score: } 30\end{array}$ \\
\hline $\begin{array}{l}\text { Result: } \\
\text { Change in outcome } \\
\text { score }\end{array}$ & $\begin{array}{l}\text { Vitamin D } 300,000 \text { IU } 26.7 \text { to } 17.4 \\
\text { Vitamin D } 150,000 \text { IU } 27.5 \text { to } 20.6 \\
\text { Nothing } 26.4 \text { to } 24.3\end{array}$ & $\begin{array}{l}\text { Vitamin D } 4.5 \text { to } 3.9 \\
\text { Placebo } 4.6 \text { to } 4.0 \\
\text { Depression decreased in both groups: } \\
\text { vitamin D } 23 \% \text {; placebo } 29 \%\end{array}$ & $\begin{array}{l}\text { BDI: } \\
\text { Vitamin D } 32.45 \text { to } 13.2 \\
\text { Comparator } 31.65 \text { to } 17.95 \\
\text { HDRS: } \\
\text { Vitamin D } 29.4 \text { to } 11.7 \\
\text { Comparator } 30.2 \text { to } 17.2\end{array}$ \\
\hline $\begin{array}{l}\text { Statistical } \\
\text { significance }\end{array}$ & Yes: placebo vs. $300,000 \mathrm{IU}$ & No & Yes \\
\hline $\begin{array}{l}\text { Clinical } \\
\text { significance }\end{array}$ & Yes & No & Yes \\
\hline Other issues & $\begin{array}{l}\text { Weaknesses: Poor randomization (random } \\
\text { number table) and unclear allocation } \\
\text { concealment } \\
\text { No power calculation } \\
\text { No intention-to-treat analysis }\end{array}$ & $\begin{array}{l}\text { Strengths: Randomization and allocation } \\
\text { concealment described, intention-to-treat } \\
\text { analysis done } \\
\text { Weaknesses: Subgroup analysis (without } \\
\text { power calculation) } \\
15 \% \text { did not complete the Geriatric } \\
\text { Depression Scale }\end{array}$ & $\begin{array}{l}\text { Weaknesses: Unclear } \\
\text { randomization and allocation } \\
\text { concealment } \\
\text { No power calculation } \\
\text { No intention to treat analysis }\end{array}$ \\
\hline
\end{tabular}

\section{Bottom Line}

Vitamin D supplementation does not improve mental wellbeing scores in the general population without clear depression, even when 25-OHD levels are low. Vitamin D supplementation in patients with depression has conflicting, poorquality evidence and cannot be recommended.

\section{BELIEF 5: VITAMIN D CAN PREVENT OR TREAT RHEUMATOID ARTHRITIS (RA)}

\section{Observational Studies}

In a prospective cohort study $(n=29,368)$ of women from Iowa (USA) aged 55-69 with no history of RA at baseline, 152 developed RA over 11 years of follow-up. When

Table 4 Vitamin D and Depression (Systematics Reviews)

\begin{tabular}{|c|c|c|c|}
\hline $\begin{array}{l}\text { Systematic review/ } \\
\text { Meta-analysis }\end{array}$ & Shaffer $2014^{50}$ & Li 2014 & Spedding 2014 \\
\hline $\begin{array}{l}\text { Number of } \\
\text { randomized } \\
\text { controlled trials } \\
\text { (patients) }\end{array}$ & $7(3191)$ & $6(1203)$ & 15 (not provided) \\
\hline $\begin{array}{l}\text { Inclusion criteria } \\
\text { (effect of vitamin D } \\
\text { on depression) } \\
\text { Result }\end{array}$ & $\begin{array}{l}\text { Patients with and without significant } \\
\text { depression }\end{array}$ & $\begin{array}{l}\text { Adults at risk of depression, with } \\
\text { depression symptoms or with } \\
\text { depression }\end{array}$ & No further criteria specified \\
\hline Bottom Line & $\begin{array}{l}\text { Reduction in depressive symptoms small } \\
\text { and non-significant }\end{array}$ & $\begin{array}{l}\text { Insufficient evidence that vitamin D } \\
\text { supplementation can improve mood }\end{array}$ & $\begin{array}{l}\text { Statistically significant improvement in } \\
2 \text { RCTs reporting outcomes on Beck } \\
\text { Depression Inventory }\end{array}$ \\
\hline $\begin{array}{l}\text { Improvement in } \\
\text { depression symptoms }\end{array}$ & $\begin{array}{l}\text { Standardized mean difference } *=-0.14 \\
(95 \% \mathrm{CI}-0.33 \text { to } 0.05) p=0.16\end{array}$ & $\begin{array}{l}\text { Standardized mean difference } *=-0.14 \\
(95 \% \mathrm{CI}-0.41 \text { to } 0.13) \\
p=0.32\end{array}$ & $\begin{array}{l}\text { Improvement on Beck Depression } \\
\text { Inventory }=0.78(95 \% \text { CI } 0.24-1.27)\end{array}$ \\
\hline Other issues & $\begin{array}{l}\text { Post hoc analysis included } 2 / 3 \mathrm{RCTs} \text { of } \\
\text { patients with depression }{ }^{47,49} \text { showing } \\
\text { statistically significant reduction in de- } \\
\text { pressive symptoms: standardized mean } \\
\text { difference* }=-0.60(95 \% \mathrm{CI}=-1.19 \text { to } \\
-0.01), p=0.046 \\
\text { Weaknesses: Analysis excluded } \\
\text { Yalamanchili } 2012,{ }^{48} \text { the one trial that } \\
\text { found no benefit }\end{array}$ & $\begin{array}{l}\text { Included } 2 / 3 \text { RCTs that looked spe- } \\
\text { cifically at patients with depression } \\
\text { (Yalamanchili } 2012^{48} \text { and Mozaffari- } \\
\text { Khosravi } 2012^{47} \text { ) }\end{array}$ & $\begin{array}{l}6 \text { RCTs included other possibly active } \\
\text { components in the active intervention } \\
\text { arm }^{53-55} \text { or compared vitamin D to } \\
\text { other possibly active interventions } \\
\text { Beck Depression Inventory in the } 2 \\
\text { combined RCTs statistically significant } \\
\text { but not clinically significant (estimated } \\
\text { to be a } 4-5 \text {-point change) } \\
\text { Weaknesses: Selective reporting of } \\
\text { studies }{ }^{45} \text { and use of per-protocol } \\
\text { analysis }\end{array}$ \\
\hline
\end{tabular}

* Standardized mean difference is a statistical measure used to combine different scales. It has limited clinical meaning, but it is generally agreed that differences smaller than 0.2 (or -0.2$)$ are not clinically meaningful. ${ }^{60}$ 
participants were divided into groups according to their vitamin D intake, those with the highest intake had a lower risk of developing RA than those with the lowest intake (RR 0.67, $95 \%$ CI 0.44-1.00). In subgroups of vitamin D intake, both higher dietary (RR 0.72, $95 \%$ CI 0.46-1.14) and supplemental vitamin D (RR 0.66, $95 \%$ CI 0.43-1.00) were associated with lower risk. This study suggests a possible relationship between low vitamin $\mathrm{D}$ intake and increased risk of RA. ${ }^{9}$ However, a larger cohort study ( $n=186,389$ women) failed to demonstrate a relationship between vitamin $\mathrm{D}$ intake and the incidence of RA or systemic lupus erythematosus. ${ }^{10}$

\section{RCTs}

Prevention. Participants enrolled in the Women's Health Initiative trial ( $n=36,282$, mean age 62$)$ were randomized to a daily dose of $1000 \mathrm{mg}$ calcium carbonate plus $400 \mathrm{IU}$ vitamin $\mathrm{D}$ or placebo for an average of 5.1 years. In intention-to-treat analyses, there were no differences in RA incidence (RR 1.04, $95 \%$ CI 0.76-1.41). ${ }^{61}$

Treatment. We identified three small $\mathrm{RCTs}^{62-64}$ in patients with RA (Table 5), all with substantial issues with quality. One study $^{64}$ from Sweden, published over 40 years ago, reported that $31 \%$ more patients on high-dose vitamin D (100,000 IU/ day) had clinical improvements at 1 year. The authors, however, provided no explanation regarding the specific subjective and objective outcomes measured. The Iranian study found no effect on Disease Activity Score or any other clinical outcome. ${ }^{62}$ The Indian study found no difference in time to pain relief (their primary outcome), but reported that patients in the vitamin $\mathrm{D}$ arm had greater improvement in pain at 3 months on a visual analogue scale (VAS; median 50 vs. $30 \%$ control group, $p=0.006){ }^{63}$ The authors mistakenly tried to convert this continuous score difference to a number needed to treat.
Overall, given the inconsistent results and high risk of bias, there is no reliable evidence that vitamin D supplementation improves outcomes in RA.

\section{Bottom Line}

Vitamin D supplementation lacks consistent and reliable evidence in preventing or treating RA.

\section{BELIEF 6: VITAMIN D CAN TREAT MULTIPLE SCLEROSIS (MS)}

\section{Observational Studies}

Observational studies have failed to demonstrate a consistent association between vitamin D levels and MS. ${ }^{5}$ However, the association between increasing latitude and increasing prevalence of MS inevitably led some to hypothesize that lower exposure to ultraviolet radiation, and thereby lower vitamin D, at high latitudes contributes to or causes MS. ${ }^{11}$ Furthermore, some observational studies have drawn associations between higher disease activity among MS patients and lower vitamin D levels. ${ }^{12,13}$

\section{Systematic Reviews/Meta-Analyses}

We could not identify any high-level evidence of vitamin $\mathrm{D}$ for the prevention of MS. Three systematic reviews/metaanalyses $^{65-67}$ have examined the effect of vitamin D on MS (Table 6). The systematic reviews themselves have some methodological concerns. They included up to five of six possible trials. The six trials were small and had several methodological weaknesses. Among these, one found a positive change in MRI lesions and another found one positive clinical outcome out of seven. The one systematic review ${ }^{66}$

Table 5 Vitamin D and Rheumatoid Arthritis Treatment (Randomized Controlled Trials)

\begin{tabular}{|c|c|c|c|}
\hline $\begin{array}{l}\text { Randomized } \\
\text { controlled trial }\end{array}$ & Salesi $2012^{62}$ & Gopinath $2011^{63}$ & Brohult $1973^{64}$ \\
\hline Population & $\begin{array}{l}\text { Rheumatoid arthritis patients in } \\
\text { Iran on methotrexate, mean age } \\
50,91 \% \text { women }\end{array}$ & $\begin{array}{l}\text { Rheumatoid arthritis patients in India on } \\
\text { three disease-modifying antirheumatic } \\
\text { drugs, mean age } 45,75 \% \text { women }\end{array}$ & $\begin{array}{l}\text { RA patients in Sweden, mean age 52, } 68 \% \\
\text { women }\end{array}$ \\
\hline $\begin{array}{l}\text { Number of } \\
\text { participants }\end{array}$ & 117 & 121 & 50 \\
\hline Vitamin D & 50,000 IU/week & $500 \mathrm{IU} /$ day & $100,000 \mathrm{IU} /$ day \\
\hline Duration & 12 weeks & 12 weeks & 1 year \\
\hline Primary outcome & $\begin{array}{l}\text { Reduction in Disease Activity } \\
\text { Score }\end{array}$ & Time to pain relief & $\begin{array}{l}\text { Subjective and objective improvement on } 4 \text { - } \\
\text { point scale }\end{array}$ \\
\hline Result & $\begin{array}{l}\text { No effect (in primary or any } \\
\text { secondary outcome) }\end{array}$ & $\begin{array}{l}\text { No effect on time to pain relief } \\
\text { One secondary endpoint statistically better } \\
(p=0.006) \text { : median pain score at trial end } \\
\text { was } 50 \% \text { better for vitamin D vs. } 30 \% \\
\text { better for placebo }\end{array}$ & $\begin{array}{l}\text { Subjective and objective improvement attained } \\
\text { in } 67 \% \text { of vitamin D group }(67 \%) \text { vs. } 36 \% \text { of } \\
\text { placebo group, } p<0.01 \text {, number needed to } \\
\text { treat }=4\end{array}$ \\
\hline Other issues & $\begin{array}{l}\text { Weaknesses: No sample size } \\
\text { calculation } \\
\text { Inadequate description of } \\
\text { randomization, allocation } \\
\text { concealment, and blinding } \\
\text { Appears analysis was not } \\
\text { intention-to-treat }\end{array}$ & $\begin{array}{l}\text { Strengths: Analysis by intention-to-treat and } \\
\text { sample size estimation } \\
\text { Weaknesses: No blinding } \\
\text { Inadequate description of randomization and } \\
\text { allocation concealment } \\
\text { Incorrect calculation of number needed to } \\
\text { treat }\end{array}$ & $\begin{array}{l}\text { Weaknesses: No sample size calculation } \\
\text { Inadequate description of randomization, } \\
\text { allocation concealment, and blinding } \\
\text { Primary outcome (subjective and objective } \\
\text { findings) not described } \\
\text { Unclear whether intention-to-treat analysis } \\
\text { done } \\
>40 \text {-year-old study may not mirror present }\end{array}$ \\
\hline
\end{tabular}


Table 6 Vitamin D and Multiple Sclerosis (Systematic Reviews)

\begin{tabular}{|c|c|c|c|}
\hline $\begin{array}{l}\text { Systematic review/ } \\
\text { Meta-analysis }\end{array}$ & Pozuelo-Moyano $2013^{65}$ & James $2013^{66}$ & Jagannath $2010^{67}$ \\
\hline Population & $\begin{array}{l}\text { Multiple sclerosis patients } \\
\text { (primarily relapsing-remitting) }\end{array}$ & Multiple sclerosis patients & $\begin{array}{l}\text { Clinically confirmed multiple } \\
\text { sclerosis patients, mean age } 40\end{array}$ \\
\hline $\begin{array}{l}\text { Number of randomized } \\
\text { controlled trials (patients) }\end{array}$ & $5(265)$ & $5(254)$ & $1(49)^{*}$ \\
\hline Vitamin D & Variable dosing/regimens & $\begin{array}{l}\text { Approximately } 3,000 \text { to } \\
40,000 \mathrm{IU} / \text { day }\end{array}$ & $\begin{array}{l}\text { Escalating vitamin D dose to } \\
\max 280,000 \mathrm{IU} / \text { week }\end{array}$ \\
\hline Duration & 6 months to 2 years & 6 months to 2 years & 1 year \\
\hline Outcome & $\begin{array}{l}\text { Clinical efficacy or toxicity of } \\
\text { vitamin } \mathrm{D} \text { in patients with } \\
\text { multiple sclerosis }\end{array}$ & One or more relapses & $\begin{array}{l}\text { Effect on relapse rate } \\
\text { Proportion with relapse }\end{array}$ \\
\hline Result & $\begin{array}{l}4 / 5 \text { trials showed no effect on } \\
\text { any outcome; only one trial } \\
\text { showed improvement in magnetic } \\
\text { resonance imaging (MRI) of lesions } \\
\text { (but not clinical outcomes) }\end{array}$ & $\begin{array}{l}\text { Vitamin D no effect on } \\
\text { multiple sclerosis relapse } \\
\text { (odds ratio } 0.98,95 \% \\
\text { CI } 0.44-2.17 \text { ); sensitivity } \\
\text { analyses found no effect }\end{array}$ & $\begin{array}{l}\text { No statistical difference in } \\
7 \text { clinical outcomes, except } \\
8 \% \text { vitamin D } \\
\text { vs. } 37.5 \% \text { placebo had higher } \\
\text { Expanded Disability Status } \\
\text { Scale scores }\end{array}$ \\
\hline Heterogeneity & Not applicable & $I^{2}=36 \%$ & Not applicable \\
\hline Other issues & $\begin{array}{l}\text { Authors felt studies too } \\
\text { heterogeneous for meta-analysis } \\
\text { Strengths: Dual reviewers and } \\
\text { assessed trial quality } \\
\text { Weaknesses: Unclear whether } \\
\text { allocation concealment assessed } \\
\text { Trials underpowered }\end{array}$ & $\begin{array}{l}\text { Weaknesses: Unclear } \\
\text { whether dual reviewers } \\
\text { and no assessment of trial quality } \\
\text { Trials underpowered }\end{array}$ & $\begin{array}{l}\text { Weaknesses: Poor randomization } \\
\text { (draw from a hat) } \\
\text { No allocation concealment } \\
\text { No blinding } \\
\text { Power calculation based on serum } \\
\text { calcium; underpowered for } \\
\text { clinical outcomes }\end{array}$ \\
\hline
\end{tabular}

* Information drawn from the original trial ${ }^{68}$

that included a meta-analysis of the results found no effect on relapse rates in either the primary or sensitivity analyses.

\section{Bottom Line}

Although the present evidence base is poor, vitamin D supplementation does not appear to provide a clinical benefit in the treatment of MS.

\section{BELIEF 7: VITAMIN D REDUCES MORTALITY}

\section{Observational Studies}

Multiple observational studies have found a positive association between low vitamin $\mathrm{D}$ levels and an increase in all-cause mortality. ${ }^{14,15}$

\section{Systematic Reviews/Meta-Analyses}

We reviewed six of the systematic reviews/metaanalyses ${ }^{16,25,69-72}$ that examined the effect of vitamin D on mortality (Table 7). Although these are large studies, mortality was a secondary outcome for almost all included trials. A wide range of patients (community-dwelling or institutionalized, with or without chronic medical conditions or previous fractures) and doses of vitamin $\mathrm{D}_{2}$ or $\mathrm{D}_{3}$ (with or without calcium) were included. Overall, the relative reduction in mortality ranged from 4 to $11 \%$. Some of the upper confidence intervals include no effect. This is not uncommon among meta-analyses, and an interpretation of benefit should not rely entirely on statistical significance testing with confidence intervals. ${ }^{73}$ Based on these meta-analyses, the relative change in mortality may be a $2 \%$ increase to a $13 \%$ reduction, but is most likely around a $5 \%$ reduction.

Trial sequential analysis ${ }^{25}$ suggests that optimum sample size of 130,005 participants has not been reached, indicating that the estimate could change with future studies. A number of the meta-analyses ${ }^{16,69}$ also found that while vitamin $D_{3}$ was effective, vitamin $\mathrm{D}_{2}$ was ineffective. The results regarding the necessity of calcium co-administration are conflicting.

Although low 25-OHD levels have been associated with increased mortality in observational studies, it should be noted that emerging observational evidence indicates that high 25 OHD levels (>120 nmol/L) are also associated with increased mortality. ${ }^{74}$

\section{Bottom Line}

The effects of vitamin D on mortality are not consistently statistically significant. If real, the relative reductions in mortality are likely quite small $(\sim 5 \%)$.

\section{BELIEF 8: VITAMIN D REDUCES CANCER INCIDENCE AND CANCER MORTALITY}

\section{Observational Studies}

There is relatively consistent evidence from observational studies of an association between lower vitamin D levels and an elevated risk of cancer. Pooled data from observational studies show a correlation between populations in the bottom versus top one third of circulating vitamin D levels and a $14 \%$ RR increase of 1.14 (95\% CI 1.01-1.29; 5003 events) in death from cancer. ${ }^{16}$ 
Table 7 Vitamin D and Mortality (Systematic Reviews)

\begin{tabular}{|c|c|c|c|c|c|c|}
\hline $\begin{array}{l}\text { Systematic } \\
\text { review/Meta- } \\
\text { Analysis }\end{array}$ & Bjelakovic 2014 ${ }^{69}$ & $\begin{array}{l}\text { Chowdhury } \\
2014^{16}\end{array}$ & Bolland 2014 25 & Rejnmark 2012 ${ }^{70}$ & Elamin 2011 ${ }^{71}$ & Autier $2007^{72}$ \\
\hline Population & $\begin{array}{l}\text { Age }>70 \text { in most } \\
\text { trials, } 77 \% \text { women, } \\
\text { wide range of healthy } \\
\text { to institutionalized } \\
\text { patients }\end{array}$ & Mean age 56-85 & $\begin{array}{l}\text { Mean age in trials } \\
53-89, \\
24-100 \% \\
\text { women }\end{array}$ & $\begin{array}{l}\text { Mean age } 70, \\
87 \% \text { women, wide } \\
\text { range of healthy to } \\
\text { institutionalized } \\
\text { patients }\end{array}$ & $\begin{array}{l}\text { Average age } 74, \\
78 \% \text { women }\end{array}$ & $\begin{array}{l}\text { Age } 50+\text { in } \\
\text { most trials }\end{array}$ \\
\hline $\begin{array}{l}\text { Number of } \\
\text { randomized } \\
\text { controlled } \\
\text { trials (patients) }\end{array}$ & 56 trials $(95,286)$ & $22(30,716)$ & $38(81,173)$ & $24(70,528)$ & $30(72,231)$ & $\begin{array}{l}18 \text { trials } \\
(57,311)\end{array}$ \\
\hline Vitamin D & $\begin{array}{l}\text { Vitamin } \mathrm{D}_{3}, \mathrm{D}_{2} \text { or } \\
\text { active forms of } \\
\text { vitamin } \mathrm{D} \\
\text { (alfacalcidol or } \\
\text { calcitriol) } \pm \text { calcium }\end{array}$ & $\begin{array}{l}\text { Vitamin D 10- } \\
6,000 \mathrm{IU} / \text { day }\end{array}$ & $\begin{array}{l}\text { Vitamin } D(\geq 200 \\
I U) \pm \text { calcium }\end{array}$ & $\begin{array}{l}\text { Variable vitamin } D_{2} \\
\text { and } D_{3} \text { doses and } \\
\text { regimens, } \pm \text { calcium }\end{array}$ & $\begin{array}{l}\text { Majority of studies } \\
\text { used vitamin } \mathrm{D}_{3} \text { : } \\
\text { high dose } \\
(\geq 800 \mathrm{IU}) \text { and low } \\
\text { dose }(<800 \mathrm{IU}) \pm \\
\text { calcium }\end{array}$ & $\begin{array}{l}\text { Mean dose: } 528 \\
\text { IU (range 300- } \\
2000 \text { IU)/day }\end{array}$ \\
\hline Duration & $\begin{array}{l}\text { Weighted mean } 0.9 \\
\text { (alfacalcidol) to } 4.9 \\
\text { years (vitamin } D_{3} \text { ) }\end{array}$ & $\begin{array}{l}\text { Trials mean } \\
\text { follow-up: } 0.38- \\
6.8 \text { years }\end{array}$ & $\begin{array}{l}1 \text { month to } \\
7 \text { years }\end{array}$ & 3 years & $\begin{array}{l}\text { Most }(\sim 75 \%) \\
\geq 12 \text { months }\end{array}$ & $\begin{array}{l}\text { Mean } 5.7 \text { years } \\
\text { (range } 6 \text { months } \\
\text { to } 7 \text { years) }\end{array}$ \\
\hline Primary result & $\begin{array}{l}\text { Overall, vitamin D } \\
\text { decreased mortality: } \\
\text { RR } 0.97 \text { (CI } 0.94- \\
0.99 \text { ) }\end{array}$ & $\begin{array}{l}\text { Any vitamin D did } \\
\text { not alter mortality: } \\
\text { RR } 0.98(95 \% \\
\text { CI } 0.94-1.02)\end{array}$ & $\begin{array}{l}\text { Vitamin D } \\
\text { reduced } \\
\text { mortality: } \\
\text { RR } 0.96 \\
\text { (CI } 0.93-1.00 \text { ) }\end{array}$ & $\begin{array}{l}\text { Vitamin D reduced } \\
\text { mortality (hazard } \\
\text { ratio } 0.93,95 \% \mathrm{CI} \\
0.88-0.99 \text { ) }\end{array}$ & $\begin{array}{l}\text { Vitamin D non- } \\
\text { significantly re- } \\
\text { duced mortality: } \\
\text { RR } 0.96(95 \% \\
\text { CI } 0.93-1.00)\end{array}$ & $\begin{array}{l}\text { Vitamin D } \\
\text { reduced } \\
\text { mortality } \\
\text { (RR 0.93,95\% } \\
\text { CI } 0.87-0.99 \text { ) }\end{array}$ \\
\hline $\begin{array}{l}\text { Subgroup } \\
\text { analyses }\end{array}$ & $\begin{array}{l}\text { Vitamin } \mathrm{D}_{3} \text {, (but not } \\
\mathrm{D}_{2} \text { or active forms of } \\
\text { vitamin } \mathrm{D} \text { ) reduced } \\
\text { mortality } \\
\text { Trials with low risk } \\
\text { of bias and industry } \\
\text { (or not) had } \\
\text { similar findings } \\
\text { Dose of } \mathrm{D}_{3} \text { or use of } \\
\text { calcium did not alter } \\
\text { findings }\end{array}$ & $\begin{array}{l}\text { Vitamin } \mathrm{D}_{3} \\
\text { reduced mortality } \\
{[\mathrm{RR} 0.89(95 \%} \\
\mathrm{CI} 0.80-0.99)] \\
\text { but } \mathrm{D}_{2} \text { did not } \\
{[\mathrm{RR} 1.04} \\
(95 \% \mathrm{CI} \\
0.97-1.11)] \\
\text { Dose, duration, } \\
\text { location did not } \\
\text { alter findings }\end{array}$ & $\begin{array}{l}\text { Similar results } \\
\text { with or without } \\
\text { calcium (although } \\
\text { neither reached } \\
\text { statistical } \\
\text { significance) }\end{array}$ & $\begin{array}{l}\text { Vitamin D plus } \\
\text { calcium reduced } \\
\text { mortality (hazard } \\
\text { ratio } 0.91 ; 95 \% \mathrm{CI} \\
0.84-0.98 \text { ) but } \\
\text { vitamin D without } \\
\text { calcium did not }\end{array}$ & $\begin{array}{l}\text { Multiple subgroup } \\
\text { analyses (13 total) } \\
\text { did not alter } \\
\text { findings } \\
\text { (including vitamin } \\
\mathrm{D}_{3} \text { vs. } \mathrm{D}_{2} \text { ) }\end{array}$ & $\begin{array}{l}\text { Duration and } \\
\text { dose of vitamin } \\
\text { D did not alter } \\
\text { findings }\end{array}$ \\
\hline Heterogeneity & $I^{2}=0 \%$ & $\begin{array}{l}\text { Chi-square } \\
p=0.34\end{array}$ & $I^{2}=0 \%$ & $I^{2}=0-16 \%$ & $I^{2}=0 \%$ & $\begin{array}{l}\text { Chi-square } \\
p=0.52\end{array}$ \\
\hline Other issues & $\begin{array}{l}\text { Strengths: } \\
\text { Publication bias } \\
\text { unlikely } \\
54 \% \text { of trials } \\
\text { (including } 71 \% \text { of } \\
\text { participants) } \\
\text { considered as having } \\
\text { low risk of bias } \\
\text { Majority of trials } \\
\text { supported by } \\
\text { industry }\end{array}$ & $\begin{array}{l}\text { Strengths: Most } \\
\text { included trials had } \\
\text { low risk of bias }\end{array}$ & & $\begin{array}{l}\text { Strengths: } \\
\text { Individual patient } \\
\text { data meta-analysis } \\
\text { performed } \\
\text { Weaknesses: } \\
\text { Variation in } \\
\text { dose/regimens may } \\
\text { have influenced } \\
\text { results }\end{array}$ & $\begin{array}{l}\text { Weaknesses: } 13 \\
\text { subgroup analyses } \\
\text { performed } \\
\text { Trials generally of } \\
\text { moderate quality }\end{array}$ & $\begin{array}{l}\text { Strengths: } \\
\text { Publication bias } \\
\text { unlikely } \\
\text { Weaknesses: } \\
\text { Did not analyze } \\
\text { vitamin } \mathrm{D}_{3} \text { or } \\
\mathrm{D}_{2} \text { separately }\end{array}$ \\
\hline
\end{tabular}

$R R$ relative risk

\section{RCTs}

A frequently cited RCT ( $n=1179$ white women over age $55)^{75}$ demonstrated that supplementation with vitamin $\mathrm{D}$ plus calcium resulted in RR of developing cancer of 0.402 $(P=0.01)$ compared to placebo. The trial, however, had many limitations: industry-funded, secondary analysis of fracture trial, unclear allocation concealment, small number of events reported, efficacy of blinding not described, and outcome was patient reporting of new onset cancers.

\section{Systematic Reviews/Meta-Analyses}

Early systematic reviews ${ }^{27,76,77}$ included limited numbers of RCTs and did not perform meta-analyses. Generally, these reviews included the $\mathrm{RCT}^{75}$ mentioned above and nonstatistically significant RCTs to conclude that possible clinically important effects could not be ruled out.

Two meta-analyses ( 7 trials, $n=48,167 ; 18$ trials, $n=$ $50,623)^{25,78}$ have been performed more recently. Both reported that vitamin D supplementation did not alter the incidence of cancer: RR 0.99 (95\% CI 0.93-1.05), ${ }^{25}$ and RR 1.00 (95\% CI $0.94-1.06){ }^{78}$ Trial sequential analysis conducted in both metaanalyses found that the effect of vitamin D supplementation on the incidence of cancer lay within the futility boundary $(15 \% \mathrm{RR}$ reduction), and no further studies were required. ${ }^{25,78}$

The larger meta-analysis ${ }^{78}$ also assessed the effect of vitamin D supplementation on cancer mortality and found a statistically significant benefit, RR 0.88 (95\% CI $0.78-$ 
0.98). This analysis included four trials with a total of 44,492 participants, and evidence was deemed to be of low quality. Trial sequential analysis indicated that this finding could be due to random errors and that further data were required.

\section{Bottom Line}

Vitamin D supplementation does not reduce the incidence of cancer. The impact of vitamin D supplementation on cancer mortality is less clear and has been assessed only by lowquality evidence.

\section{BELIEF 9: VITAMIN D DOSE-MORE IS BETTER}

\section{RCTs}

Two large RCTs (Table 8) provide concerning evidence that higher doses of vitamin D could increase the risk of falls and fracture. ${ }^{79,80}$ Given the present enthusiasm for vitamin D supplementation and the pervasive belief that more is better, these trials serve as a good reminder. Even in the two clinical areas of best evidence for vitamin D supplementation (falls and fracture prevention), massive doses can increase the very outcomes we are trying to prevent. Additionally, there is some evidence (albeit observational) that higher 25-OHD levels $(>120 \mathrm{nmol} / \mathrm{L})$ are associated with increased mortality. ${ }^{74}$

\section{Bottom Line}

High-dose vitamin D has been shown to increase the risk of falls and fractures. Single high-dose ( $\geq 300,000 \mathrm{IU})$ supplementation should not be recommended.

\section{BELIEF 10: VITAMIN D (25-OHD) LEVELS SHOULD BE TESTED ROUTINELY}

Routine 25-OHD testing is not recommended, for several reasons. Vitamin D assays can vary by as much as $10-20 \%$, even when repeating the test in the same person at the same time. ${ }^{5}$ Therefore, changes in levels may not be discernable in individuals at doses of $800 \mathrm{IU} / \mathrm{day}$, as this dose on average changes the serum vitamin $\mathrm{D}$ about as much as the variance in assay. ${ }^{81}$

Enrollment in many vitamin D supplementation trials was not based on 25-OHD levels, and treatment of patients without screening 25-OHD level was found to be beneficial. ${ }^{29,72,82}$

Finally, routine screening/testing of 25-OHD levels is an onerous and costly exercise. The cost of a $25-\mathrm{OHD}$ assay is $\$ 61.32,{ }^{81}$ two to three times the cost of a year's worth of vitamin D.

Despite recommendations to the contrary, testing 25-OHD levels has become widespread in recent years. One consequence has been confusion regarding the 25-OHD level indicative of deficiency. The "cut-points" for deficiency and sufficiency used by laboratories are neither standardized nor based on rigorous scientific studies. The number of people with vitamin D insufficiency/deficiency may be overestimated, because many labs use higher cut-points than are indicated by the evidence. $^{5}$

Based on a systematic review of studies on health outcomes associated with vitamin $\mathrm{D}$, the Institute of Medicine now recommends:

- Deficiency: $<30 \mathrm{nmol} / \mathrm{L}$ places a person "at risk relative to bone health"; $30-50 \mathrm{nmol} / \mathrm{L}$ "places some, but not all, persons at risk for inadequacy."

- Sufficiency (adequate): $\geq 50 \mathrm{nmol} / \mathrm{L}$ meets the needs of $97.5 \%$ of the population

The Institute of Medicine also states that "levels $>75 \mathrm{nmol} /$ $\mathrm{L}$ are not consistently associated with increased benefit."

\section{Bottom Line}

Vitamin D supplementation in the general adult population is safe, and supplementation without testing is reasonable. Testing may be appropriate when clinically indicated (e.g.,

Table 8 Examples of Vitamin D Mega-Dose (Randomized Controlled Trials)

\begin{tabular}{|c|c|c|}
\hline Randomized controlled trial & Sanders 2010 & Smith $2007^{80}$ \\
\hline Population & $\begin{array}{l}\text { Age } \geq 70 \text { with high risk of fracture, women only, } \\
\text { community-dwelling }\end{array}$ & Age $\geq 75,54 \%$ women, community-dwelling \\
\hline Number of participants & 2256 & 9440 \\
\hline Vitamin D & $500,000 \mathrm{IU} /$ year (single oral dose each autumn) & $300,000 \mathrm{IU} \mathrm{D} \mathrm{D}_{2}$ (single intramuscular injection each autumn) \\
\hline Duration & $3-5$ years (mean 3.1 years) & 3 years \\
\hline Outcome & Falls and fractures & $\begin{array}{l}\text { Primary: all non-vertebral fractures } \\
\text { Secondary: hip and wrist fractures, all falls }\end{array}$ \\
\hline Result & $\begin{array}{l}\text { Increased falls (rate ratio } 1.15,95 \% \text { CI } 1.02-1.30 \text { ) } \\
\text { and fractures (rate ratio } 1.26,95 \% \text { CI } 1.00-1.59 \text { ) } \\
\text { Statistically significant temporal pattern evident for } \\
\text { falls-highest incidence within first } 3 \text { months of } \\
\text { supplementation when vitamin D levels }>90 \mathrm{nmol} / \mathrm{L} \\
\text { Number needed to harm over } 3.1 \text { years of } 18 \mathrm{for} \\
\text { falls and } 32 \text { for fractures }\end{array}$ & $\begin{array}{l}\text { Risk increased for all fractures (hazard ratio } 1.09 \text {; } \\
95 \% \text { CI } 0.93-1.28 \text { ) } \\
\text { One fracture subgroup statistically significant: excess } \\
\text { risk of hip fracture in those on vitamin D (hazard } \\
\text { ratio } 1.49 ; 95 \% \text { CI } 1.02-2.18 \text { ) } \\
\text { No effect on falls (hazard ratio } 0.98,95 \% \text { CI } \\
0.93-1.04 \text { ) }\end{array}$ \\
\hline Other issues & $\begin{array}{l}\text { Strengths: Good randomization, allocation } \\
\text { concealment } \\
\text { and blinding } \\
\text { Sample size calculation done } \\
\text { Daily fall recording }\end{array}$ & $\begin{array}{l}\text { Strengths: Good randomization, allocation } \\
\text { concealment and blinding } \\
\text { Sample size calculation done } \\
\text { Weaknesses: } 6 \text {-month recall of falls }\end{array}$ \\
\hline
\end{tabular}


parathyroid disease), and a variety of resources are available to direct testing. ${ }^{83}$ When testing is performed, $\geq 50 \mathrm{nmol} / \mathrm{L}$ indicates vitamin D sufficiency.

\section{CONCLUSION}

Severe vitamin D deficiency causes important health problems (e.g., rickets). Additionally, lower 25-OHD levels have sometimes been associated with a long list of medical conditions and negative outcomes. However, association is not causation, and high-quality, high-level evidence for supplementation is frequently lacking. Vitamin D may prove to be a good surrogate for general well-being.

At the present time, evidence supports vitamin D supplementation to help prevent fractures (particularly if given with calcium), and possibly to prevent falls and slightly reduce mortality (particularly in older patients [ $>70$ years of age]). No other effects are proven. For many other conditions, the evidence for vitamin D supplementation is plagued by the use of small, poor-quality trials. Lastly, testing of 25-OHD levels in the general population is not necessary, and very high doses should be avoided.

Acknowledgments: There are no additional contributors to the manuscript. The project received no funding, and this work has not been presented previously.

Corresponding Author: G. Michael Allan, MD; Evidence-Based Medicine, Department of Family Medicine - Research Program University of Alberta, 6-10 University Terrace, Edmonton, AB T6G 2T4, Canada (e-mail: michael.allan@ualberta.ca).

\section{Compliance with Ethical Standards:}

Conflict of Interest: The authors declare that they have no conflict of interest.

\section{REFERENCES}

1. Autier P, Boniol M, Pizot C, Mullie P. Vitamin D status and ill health: a systematic review. Lancet Diabetes Endocrinol. 2014;2(1):76-89.

2. Stein MS, Wark JD, Scherer SC, et al. Falls relate to vitamin D and parathyroid hormone in an Australian nursing home and hostel. J Am Geriatr Soc. 1999;47(10):1195-1201.

3. Flicker L, Mead K, MacInnis RJ, et al. Serum vitamin D and falls in older women in residential care in Australia. J Am Geriatr Soc. 2003;51(11):1533-1538.

4. Sambrook PN, Chen JS, March LM, et al. Serum parathyroid hormone predicts time to fall independent of vitamin D status in a frail elderly population. J Clin Endocrinol Metab. 2004;89(4):15721576 .

5. Institute of Medicine. Dietary Reference Intakes for Calcium and Vitamin D. Washington, DC. 2011.

6. Lai JK, Lucas RM, Clements MS, Roddam AW, Banks E. Hip fracture risk in relation to vitamin D supplementation and serum 25hydroxyvitamin D levels: a systematic review and meta-analysis of randomised controlled trials and observational studies. BMC Public Health. 2010;10:331.

7. Ginde AA, Mansbach JM, Camargo CA Jr. Association between serum 25-hydroxyvitamin D level and upper respiratory tract infection in the Third National Health and Nutrition Examination Survey. Arch Intern Med. 2009; 169(4):384-390.

8. Anglin RE, Samaan Z, Walter SD, McDonald SD. Vitamin D deficiency and depression in adults: systematic review and meta-analysis. $\mathrm{Br} \mathrm{J}$ Psychiatry. 2013;202:100-107.
9. Merlino LA, Curtis J, Mikuls TR, et al. Vitamin D intake is inversely associated with rheumatoid arthritis: results from the Iowa Women's Health Study. Arthritis Rheum. 2004;50(1):72-77.

10. Costenbader KH, Feskanich D, Holmes M, Karlson EW, Benito-Garcia E. Vitamin D intake and risks of systemic lupus erythematosus and rheumatoid arthritis in women. Ann Rheum Dis. 2008;67(4):530-535.

11. Simpson S Jr, Blizzard L, Otahal P, Van der Mei I, Taylor B. Latitude is significantly associated with the prevalence of multiple sclerosis: a metaanalysis. J Neurol Neurosurg. 2011;82(10):1132-1141.

12. Soilu-Hanninen M, Laaksonen M, Laitinen I, Eralinna JP, Lilius EM, Mononen I. A longitudinal study of serum 25-hydroxyvitamin D and intact parathyroid hormone levels indicate the importance of vitamin D and calcium homeostasis regulation in multiple sclerosis. J Neurol Neurosurg Psychiatry. 2008;79(2): 152-157.

13. van der Mei IA, Ponsonby AL, Dwyer T, et al. Vitamin D levels in people with multiple sclerosis and community controls in Tasmania, Australia. J Neurol. May. 2007;254(5):581-590.

14. Hutchinson MS, Grimnes G, Joakimsen RM, Figenschau Y, Jorde R. Low serum 25-hydroxyvitamin D levels are associated with increased allcause mortality risk in a general population: the Tromso study. Eur J Endocrinol. 2010;162(5):935-942.

15. Ginde AA, Scragg R, Schwartz RS, Camargo CA Jr. Prospective study of serum 25-hydroxyvitamin D level, cardiovascular disease mortality, and all-cause mortality in older U.S. adults. J Am Geriatr Soc. 2009;57(9):1595-1603.

16. Chowdhury R, Kunutsor S, Vitezova A, et al. Vitamin D and risk of cause specific death: systematic review and meta-analysis of observational cohort and randomised intervention studies. BMJ. 2014;348:g1903.

17. Cameron ID, Gillespie LD, Robertson MC, et al. Interventions for preventing falls in older people in care facilities and hospitals. Cochrane Database Syst Rev. 2012;12, CD005465.

18. Gillespie LD, Robertson MC, Gillespie WJ, et al. Interventions for preventing falls in older people living in the community. Cochrane Database Syst Rev. 2012;9, CD007146.

19. Bischoff-Ferrari HA, Dawson-Hughes B, Staehelin HB, et al. Fall prevention with supplemental and active forms of vitamin D: a metaanalysis of randomised controlled trials. BMJ. 2009;339:b3692.

20. Michael YL, Whitlock EP, Lin JS, et al. Primary care-relevant interventions to prevent falling in older adults: a systematic evidence review for the U.S. Preventive Services Task Force. Ann Intern Med. 2010;153(12):815825.

21. Kalyani RR, Stein B, Valiyil R, Manno R, Maynard JW, Crews DC. Vitamin D treatment for the prevention of falls in older adults: systematic review and meta-analysis. J Am Geriatr Soc. 2010;58(7):1299-1310.

22. Murad MH, Elamin KB, Abu Elnour NO, et al. Clinical review: The effect of vitamin D on falls: a systematic review and meta-analysis. $\mathrm{J}$ Clin Endocrinol Metab. 2011;96(10):2997-3006.

23. Cranney A, Horsley T, O'Donnell S, et al. Effectiveness and safety of vitamin D in relation to bone health. Evid Rep Technol Assess (Full Rep). 2007; 158: 1-235.

24. Bolland MJ, Grey A, Gamble GD, Reid IR. Vitamin D supplementation and falls: a trial sequential meta-analysis. Lancet Diabetes Endocrinol. 2014;2(7):573-580.

25. Bolland MJ, Grey A, Gamble GD, Reid IR. The effect of vitamin D supplementation on skeletal, vascular, or cancer outcomes: a trial sequential meta-analysis. Lancet Diabetes Endocrinol. 2014;2(4):307-320.

26. Bischoff-Ferrari HA, Willett WC, Orav EJ, et al. A pooled analysis of vitamin $\mathrm{D}$ dose requirements for fracture prevention. N Engl $\mathrm{J}$ Med. 2012;367(1):40-49.

27. Chung M, Lee J, Terasawa T, Lau J, Trikalinos TA. Vitamin D with or without calcium supplementation for prevention of cancer and fractures: an updated meta-analysis for the U.S. Preventive Services Task Force. Ann Intern Med. 2011;155(12):827-838.

28. Avenell A, Mak JCS, O'Connell D. Vitamin D and vitamin D analogues for preventing fractures in post-menopausal women and older men. Cochrane Database Syst Rev. 2014;4, CD000227.

29. Bischoff-Ferrari HA, Willett WC, Wong JB, et al. Prevention of nonvertebral fractures with oral vitamin D and dose dependency: a metaanalysis of randomized controlled trials. Arch Intern Med. 2009; 169(6):551-561.

30. Bergman $\mathbf{P}$, Lindh AU, Bjorkhem-Bergman L, Lindh JD. Vitamin D and Respiratory Tract Infections: A Systematic Review and Meta-Analysis of Randomized Controlled Trials. PloS One. 2013;8(6), e65835.

31. Charan J, Goyal JP, Saxena D, Yadav P. Vitamin D for prevention of respiratory tract infections: A systematic review and meta-analysis. $J$ Pharmacol Pharmacother. 2012;3(4):300-303. 
32. Mao S, Huang $\mathbf{S}$. Vitamin D supplementation and risk of respiratory tract infections: a meta-analysis of randomized controlled trials. Scand J Infect Dis. 2013;45(9):696-702

33. Laaksi I, Ruohola JP, Mattila V, Auvinen A, Ylikomi T, Pihlajamaki H. Vitamin D supplementation for the prevention of acute respiratory tract infection: a randomized, double-blinded trial among young Finnish men. J Infect Dis. 2010;202(5):809-814.

34. Urashima M, Segawa T, Okazaki M, Kurihara M, Wada Y, Ida $\mathbf{H}$. Randomized trial of vitamin D supplementation to prevent seasonal influenza A in schoolchildren. Am J Clin Nutr. 2010;91(5):12551260

35. Allan GM, Martino F. Vitamin D and respiratory tract infections: Does the sun's vitamin chase the cold? Tools for Practice. 2014; October 27, 124. Available at: https://www.acfp.ca/wp-content/uploads/tools-for-practice/ 1416503637 tfpvitdandurtifvupdated.pdf Accessed February 10, 2016.

36. Murdoch DR, Slow S, Chambers ST, et al. Effect of vitamin D3 supplementation on upper respiratory tract infections in healthy adults: the VIDARIS randomized controlled trial. JAMA. 2012;308(13): 1333-1339.

37. Manaseki-Holland S, Maroof Z, Bruce $\mathbf{J}$, et al. Effect on the incidence of pneumonia of vitamin D supplementation by quarterly bolus dose to infants in Kabul: a randomised controlled superiority trial. Lancet. 2012;379(9824):1419-1427.

38. Camargo CA Jr, Ganmaa D, Frazier AL, et al. Randomized trial of vitamin D supplementation and risk of acute respiratory infection in Mongolia. Pediatrics. 2012;130(3):e561-567.

39. Bertone-Johnson ER, Powers SI, Spangler L, et al. Vitamin D supplementation and depression in the women's health initiative calcium and vitamin D trial. Am J Epidemiol. 2012;176(1):1-13.

40. Kjaergaard $\mathbf{M}$, Waterloo $\mathbf{K}$, Wang $\mathbf{C E}$, et al. Effect of vitamin D supplement on depression scores in people with low levels of serum 25hydroxyvitamin D: nested case-control study and randomised clinical trial. Br J Psychiatry. 2012;201(5):360-368.

41. Dean AJ, Bellgrove MA, Hall T, et al. Effects of vitamin D supplementation on cognitive and emotional functioning in young adults-a randomised controlled trial. PloS One. 2011;6(11), e25966.

42. Sanders KM, Stuart AL, Williamson EJ, et al. Annual high-dose vitamin D3 and mental well-being: randomised controlled trial. Br J Psychiatry. 2011;198(5):357-364.

43. Arvold DS, Odean MJ, Dornfeld MP, et al. Correlation of symptoms with vitamin D deficiency and symptom response to cholecalciferol treatment: a randomized controlled trial. Endocr Pract. 2009; 15(3):203-212.

44. Jorde R, Sneve M, Figenschau Y, Svartberg J, Waterloo K. Effects of vitamin D supplementation on symptoms of depression in overweight and obese subjects: randomized double blind trial. J Intern Med. 2008;264(6):599-609.

45. Vieth R, Kimball S, Hu A, Walfish PG. Randomized comparison of the effects of the vitamin D3 adequate intake versus $100 \mathrm{mcg}$ (4000 IU) per day on biochemical responses and the wellbeing of patients. Nutr J. 2004;3:8.

46. Harris S, Dawson-Hughes B. Seasonal mood changes in 250 normal women. Psychiatry Res. 1993;49(1):77-87.

47. Mozaffari-Khosravi H, Nabizade L, Yassini-Ardakani SM, Hadinedoushan $\mathbf{H}$, Barzegar $\mathbf{K}$. The effect of 2 different single injections of high dose of vitamin $\mathrm{D}$ on improving the depression in depressed patients with vitamin D deficiency: a randomized clinical trial. J Clin Psychopharmacol. 2013;33(3):378-385.

48. Yalamanchili V, Gallagher JC. Treatment with hormone therapy and calcitriol did not affect depression in older postmenopausal women: no interaction with estrogen and vitamin D receptor genotype polymorphisms. Menopause. 2012;19(6):697-703.

49. Khoraminya N, Tehrani-Doost M, Jazayeri S, Hosseini A, Djazayery A. Therapeutic effects of vitamin D as adjunctive therapy to fluoxetine in patients with major depressive disorder. Aust N Z J Psychiatry. 2013:47(3):271-275.

50. Shaffer JA, Edmondson D, Wasson LT, et al. Vitamin D supplementation for depressive symptoms: a systematic review and meta-analysis of randomized controlled trials. Psychosom Med. 2014;76(3):190-196.

51. Li G, Mbuagbaw L, Samaan Z, et al. Efficacy of vitamin D supplementation in depression in adults: a systematic review. J Clin Endocrinol Metab. 2014;99(3):757-767.

52. Spedding $\mathbf{S}$. Vitamin D, and depression: a systematic review and metaanalysis comparing studies with and without biological flaws. Nutrients. 2014;6(4): 1501-1518.

53. Belcaro G, Cesarone MR, Cornelli U, Dugall M. MF Afragil(R) in the treatment of 34 menopause symptoms: a pilot study. Panminerva Med. 2010;52(2 Suppl 1):49-54.
54. Khajehei M, Abdali K, Parsanezhad ME, Tabatabaee HR. Effect of treatment with dydrogesterone or calcium plus vitamin D on the severity of premenstrual syndrome. Int $\mathrm{J}$ Gynaecol Obstet. 2009;105(2):158-161.

55. Dumville JC, Miles JN, Porthouse J, Cockayne S, Saxon L, King C. Can vitamin D supplementation prevent winter-time blues? A randomised trial among older women. J Nutr Health Aging. 2006;10(2): 151-153.

56. Gloth FM 3rd, Alam W, Hollis B. Vitamin D vs broad spectrum phototherapy in the treatment of seasonal affective disorder. J Nutr Health Aging. 1999;3(1):5-7

57. Lansdowne AT, Provost SC. Vitamin D3 enhances mood in healthy subjects during winter. Psychopharmacology (Berl). 1998;135(4):319323

58. Zhang M, Robitaille L, Eintracht S, Hoffer LJ. Vitamin C provision improves mood in acutely hospitalized patients. Nutrition. 2011;27(5):530533.

59. Dworkin RH, Turk DC, Wyrwich KW, et al. Interpreting the clinical importance of treatment outcomes in chronic pain clinical trials: IMMPACT recommendations. J Pain. 2008;9(2):105-121.

60. Cummings P. Arguments for and against standardized mean differences (effect sizes). Arch Pediatr Adolesc Med. 2011;165(7):592-6.

61. Racovan M, Walitt B, Collins CE, et al. Calcium and vitamin D supplementation and incident rheumatoid arthritis: the Women's Health Initiative Calcium plus Vitamin D trial. Rheumatol Int. 2012;32(12):38233830.

62. Salesi M, Farajzadegan Z. Efficacy of vitamin D in patients with active rheumatoid arthritis receiving methotrexate therapy. Rheumatol Int. 2012;32(7):2129-2133.

63. Gopinath $\mathbf{K}$, Danda D. Supplementation of 1,25 dihydroxy vitamin D3 in patients with treatment naive early rheumatoid arthritis: a randomised controlled trial. Int J Rheum Dis. 2011;14(4):332-339.

64. Brohult J, Jonson B. Effects of large doses of calciferol on patients with rheumatoid arthritis. A double-blind clinical trial. Scand J Rheumatol. 1973;2(4):173-176.

65. Pozuelo-Moyano B, Benito-Leon J, Mitchell AJ, Hernandez-Gallego J. A systematic review of randomized, double-blind, placebo-controlled trials examining the clinical efficacy of vitamin D in multiple sclerosis. Neuroepidemiology. 2013;40(3): 147-153.

66. James E, Dobson R, Kuhle J, Baker D, Giovannoni G, Ramagopalan SV. The effect of vitamin D-related interventions on multiple sclerosis relapses: a meta-analysis. Mult Scler. 2013;19(12):1571-1579.

67. Jagannath VA, Fedorowicz Z, Asokan GV, Robak EW, Whamond L. Vitamin D for the management of multiple sclerosis. Cochrane Database Syst. 2010;12, CD008422.

68. Burton JM, Kimball S, Vieth R, et al. A phase I/II dose-escalation trial of vitamin D3 and calcium in multiple sclerosis. Neurology. 2010;74(23): 1852-1859.

69. Bjelakovic G, Gluud LL, Nikolova D, et al. Vitamin D supplementation for prevention of mortality in adults. Cochrane Database Syst. 2014;1, CD007470.

70. Rejnmark L, Avenell A, Masud T, et al. Vitamin D with calcium reduces mortality: patient level pooled analysis of 70,528 patients from eight major vitamin D trials. J Clin Endocrinol Metab. 2012;97(8):2670-2681.

71. Elamin MB, Abu Elnour NO, Elamin KB, et al. Vitamin D and cardiovascular outcomes: a systematic review and meta-analysis. J Clin Endocrinol Metab. 2011;96(7):1931-1942.

72. Autier P, Gandini S. Vitamin D supplementation and total mortality: a meta-analysis of randomized controlled trials. Arch Intern Med. 2007; 167(16): 1730-1737.

73. McCormack J, Vandermeer B, Allan GM. How confidence intervals become confusion intervals. BMC Med Res Methodol. 2013;13:134.

74. Newberry SJC M, Shekelle PG, Booth MS, et al. Vitamin D and Calcium: A Systematic Review of Health Outcomes (Update). Rockville: Evidence Report/Technology Assessment No. 217. AHRQ Publication No. 14-E004EF; 2014.

75. Lappe JM, Travers-Gustafson D, Davies KM, Recker RR, Heaney RP. Vitamin D and calcium supplementation reduces cancer risk: results of a randomized trial. Am J Clin Nutr. 2007;85(6):1586-1591.

76. Chung EMMB, Brendel M, et al. Vitamin D and calcium: a systematic review of health outcomes. Evid Rep No. 183. Rockville: Agency for Healthcare Research and Quality; 2009.

77. Lazzeroni M, Serrano D, Pilz S, Gandini S. Vitamin D supplementation and cancer: review of randomized controlled trials. Anticancer Agents Med Chem. 2013;13(1):118-125. 
78. Bjelakovic G, Gluud LL, Nikolova D, et al. Vitamin D supplementation for prevention of cancer in adults. Cochrane Database Syst Rev. 2014;6, CD007469.

79. Sanders KM, Stuart AL, Williamson EJ, et al. Annual high-dose oral vitamin D and falls and fractures in older women: a randomized controlled trial. JAMA. 2010;303(18):1815-1822.

80. Smith H, Anderson F, Raphael H, Maslin P, Crozier S, Cooper C. Effect of annual intramuscular vitamin D on fracture risk in elderly men and women-a population-based, randomized, double-blind, placebocontrolled trial. Rheumatology (Oxford). 2007;46(12):1852-1857.
81. Lindblad AJ, McCormack J. Testing Vitamin D Levels. Can Fam Physician. 2014;60(4):351.

82. Bischoff-Ferrari HA, Dawson-Hughes B, Willett WC, et al. Effect of Vitamin D on falls: a meta-analysis. JAMA. 2004;291(16):19992006.

83. Toward Optimized Practice (TOP) Working Group for Vitamin D. Guideline for Vitamin D Testing and Supplementation in Adults. 2014. Available at: http://www.topalbertadoctors.org/download/1304/Vitamin\%20D\%20Testing\%20and\%20Supplementation.pdf Accessed February 10, 2016. 